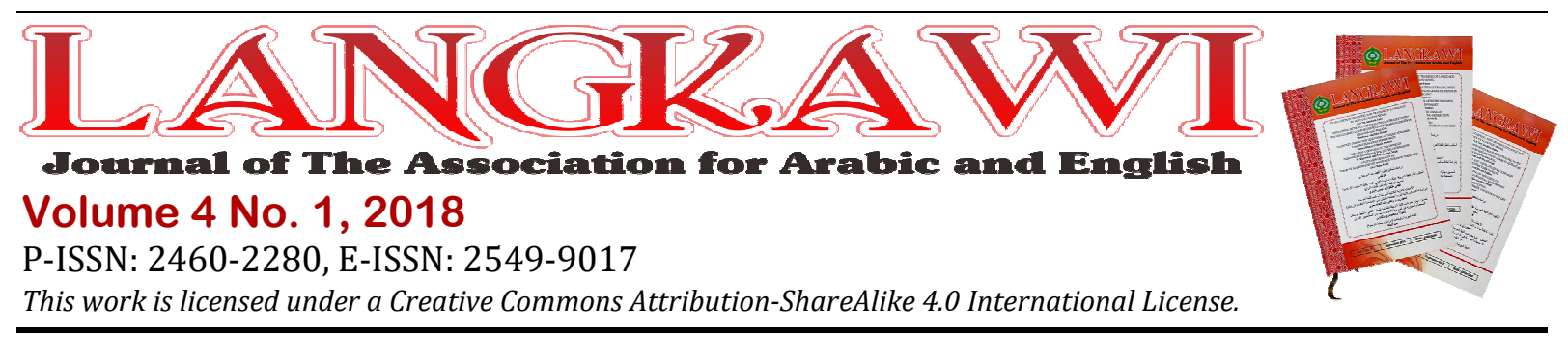

\title{
The Concept of 'Home' in Palestinian Diaspora Fiction: A Critical Study of Randa Jarrar's Fiction
}

\section{Jameel Ahmed Alghaberi ${ }^{1}$}

${ }^{1}$ Ph.D. Research Scholar at Saurashtra University, India; Teaching Assistant at Thamar University, Yemen E-mail: abujamaljameel@gmail.com

\begin{tabular}{l} 
ARTICLE INFO \\
\hline Keywords: \\
Home; Palestinian \\
Diaspora; \\
Transnationalism; Randa \\
Jarrar's Fiction \\
How to cite: \\
Alghaberi, J. A., (2018). \\
The Concept of 'Home' in \\
Palestinian Diaspora \\
Fiction: A Critical Study \\
of Randa Jarrar's Fiction, \\
4(1), 13-20. \\
DOI: \\
http://dx.doi.org/10.31332/ \\
lkw.v4i1.765
\end{tabular}

\begin{abstract}
The paper discusses the concepts of 'home', 'cultural identity', and 'transnationalism' in Randa Jarrar's fiction. Being a diasporic Palestinian American, Randa Jarrar in her debut novel A Map of Home presents a particular view of 'homeland' and of what 'historic Palestine' means to her. The attempt in this paper is to critically analyze her fiction and to highlight the issues that she tackles as a writer of Palestinian origin. The paper also explores the way Randa Jarrar approaches the concept of 'home', and an examination of the relationship between Palestinian diasporas and their homelandPalestine is presented. There is much wandering that Randa Jarrar is experimenting with in rather a creative space, and there is also a counter-narrative ideology embedded in the novel, a way to resist the stereotypes that have fixed the Middle Eastern female body as propagated in Orientalist discourse.
\end{abstract}

\section{Introduction}

The dispersion of Palestinians from their homeland is one of the harrowing catastrophes of the twentieth century. The creation of Israel in 1948 resulted in an exodus of Palestinians, rendering them displaced on their homeland and refugees in some neighbouring countries. Many of them are until today categorized as stateless, and they are denied their legitimate right to return to their villages and houses. Many also immigrated to North America and countries in Latin America, and recently some found Europe as a prime destination either as refugees or diasporas. The United Nations has failed to resolve the Palestinian-Israeli conflict, and the Jews, once traumatized and tortured in Europe, have been inflicting the same on Palestinians. Palestinian diaspora has carved a space for itself as a victim diaspora. The literature that the Palestinian diaspora writers produce mostly depicts the anguish, the suffering, and also the dream of independent state-Palestine. Their novels, short stories, and memoirs narrate the experience of the Palestinian individual in the host land. Thus, the sense of place for Palestinian diasporas is central in articulating their identity and claiming their homeland. Many writers 
attempt to anchor their characters to a particular place or places, while many others, like Randa Jarrar, cross borders and transcend cultural borderlines.

The idea of a global sense of place, or what it is termed today as 'cosmopolitanism', has also been proposed by many scholars of globalization and transnationalism. Randa Jarrar as a Palestinian American finds no other way than transnationalism to define her existence and determine her belonging. It is sometimes due to the prolonged Palestinian-Israeli conflict that some Palestinian diasporas found themselves obliged to completely integrate into the host society or freely label themselves as citizens of the world.

In the Palestinian case, place is of greater significance as the Palestinian identity is usually described as out of place and lacking centrality. Randa Jarrar is a Palestinian American whose fiction transcends space and time. She is one of the young Palestinian diaspora writers who champion the Palestinian national cause and also defy the stereotypical images of the Middle Eastern women. Her first novel, $A$ Map of Home (2008), was a grand success, acclaimed and translated into six major languages. In this connection, it is viable to say in general terms that the Palestinian diasporic and exilic writing is vibrant and highly acclaimed.

Writers of such category have been enriching the libraries of diaspora and world literature. Their literary output occupies a sizable portion in the section of victim diasporas, narrating the personal and the collective trauma of people who have been subjugated for decades. In the words of Nadia Sirhan, the very act of narrating gives credence and existence to the displaced and dispossessed Palestinians (Sirhan, 2014). It is filled with anguish and despair, yet it communicates a voice of resilience. Memoirs, short stories, and novels that continue to emerge from different diaspora societies undoubtedly give the Palestinian political question a soul and spirit; substance that the political rhetoric lacks. Asmaa Naguib (2011) in this regard observes that the Palestinian novelists have assumed the task of remembering and narrating the entire collective experience to save the story of Palestine from oblivion (Representations of 'Home' from the Setting of 'Exile': Novels by Arab Migrant Writers, Asmaa Naguib, 2011).This has been the crux in most of the Palestinian diaspora writing since 1948 which is marked in the Palestinian history as the beginning of al-Nakba (catastrophe).

Among Palestinian diasporas, Edward Said has been among the first Palestinians to vehemently advocate the cause of Palestine. He constituted a large corpus about the Palestinian-Israeli conflict but it does not receive adequate attention in the western canon. Said compellingly argues for a reassessment of the injustices on both sides of the divide between Israelis and Palestinians (Ashcroft and Ahluwalia, 2001). He initiated a 'writing back' to dismantle the western master narratives that shape the commonly held perceptions about Arab Palestinians. He had used all possible opportunities and places to put the aspirations of the Palestinian people to the international community (Yi, 2011). He was the voice of Palestine in the West, campaigning against the politics of dispossession. Today's voices are no less important but they should be no more cultural informants. What they are supposed to do is to validate the story of Palestine and add other dimensions to the Palestinian counter-narrative. The present paper attempts to critically assess the representation of Palestine in the fiction of contemporary Palestinian diaspora writer-Randa Jarrar. 
The aim is also to reflect the manifestations of Palestinian cultural identity in the fiction of such contemporary diaspora writer.

\section{Method}

The methodology used in this study is a mix of various modes of readings. The study is based on a variety of resources, including Randa Jarrar's novel A Map of Home as a primary resource and essays and memoirs by Palestinian scholars and critics as secondary resources. Extensive use has been made of exile and diaspora literature and critical articles relevant to the Palestinian diaspora. Edward Said, Randa Jarrar, Ihab Saloul, etc. embody the rich body of texts conceptualizing the Palestinian issue. The psychoanalytic method is applied in certain contexts to analyze particular characters, while the postcolonial approach is invoked in addressing the Palestinian-Israeli territorial issue. Narratology as an interpretation model is also used in deciphering the core of the Palestinian narratives.

\section{Findings and Discussion}

\section{Problematizing Palestinian Diaspora and the Right to Return}

We cannot present the term 'Palestinian diaspora' without referring to the heated argument about it. The Palestinian-Israel issue is a thorny one as both sides have repeatedly failed to understand the legitimacy of each other's narrative. Since the end of the British mandate, Palestinians have been denied statehood and they now live under what amounts to a military occupation. For any peace negotiations, it is necessary to understand the right of each side to exist and the legitimacy of each historical narrative. As it is largely known that the emergence of the state of Israel in 1948 marked the end of the Jewish diaspora, it also triggered the dispersal of Palestinians. Since that date, the Israeli state systematically dispossesses Palestinians, demolishing their villages and barring the displaced and refugees from returning to their houses. All this is done to solidify the existence of Israel and also to erase any memory of Palestine.

The world 'diaspora' is therefore problematic for some Palestinian writers as it indicates the possibility of no returning to the Palestinian homeland. Generally speaking, diasporas can create their own imagined homes in homeless conditions and they can also construct numerous social connections and communities away from home. Their idea of homeland is imaginary, and thus home is merely referred to symbolically or metaphorically. Whatever the fear of the term, Palestinian diaspora is today well-established and validated. It has made itself a concrete reality, and the concern today is to enliven such diasporas and enrich them with cultural encounters and connections with homeland. There are many writers and decisionmakers who truly recognize the significant role of Palestinian diaspora in politics, economy, culture, and national identity struggle.

There have been some arguments about the validity of the concept 'diaspora' for Palestinians abroad. In this regard, Sari Hanafi (2003) in his article "Rethinking Palestinians abroad as a Diaspora: The Relationship between the Diaspora and the Palestinian Territories", emphasizes that "the Palestinians abroad do not constitute a real diaspora, but rather a "partially diasporized people" (Rethinking Palestinians Abroad as a Diaspora: The Relationship between Diaspora and the Plestinian Territories 158). 
To explain his statement further, he constructs a typology of three different categories:(i) diasporized people, (ii) populations in transit, and (iii)assimilated populations" (Hanafi, 2003). In his analysis, he attempts to defy the definition of diaspora and thus fragmenting the essence of what constitutes the Palestinian diaspora as an entity. Nonetheless, arrival for Palestinians as victim diaspora is a sort of gain not loss. It does not indicate the erosion of Palestinian culture as many Palestinian diasporas are actively connected to their homeland through different means.

Though the structural complexity of Palestinian diaspora is recognized, there are certain prospects that can enhance their role in maintaining cultural connections and sustaining political engagements. Regardless of the exact definitions of the terms 'exile' and 'diaspora', they have both been employed to signify movement and migrancy. In fact, examining the statements about the home of diasporas provoke certain questions about the role of Palestinian diaspora in strengthening cultural identity, and promoting pro-nationalist agenda. Palestinian diasporas are today actively engaged in every aspect of their national cause and are no less concerned with the major issues of Palestine. Palestinians worldwide have remained steadfast and firm in maintaining a shared national identity since al-Nakba. But there is a sort of weakness in the relationship between the Palestinian diaspora abroad and the emerging Palestinian identity. This is due to the Israeli dominating master-narrative coupled with the brutal military force. This is indeed one of the real challenges that both Palestinian nationalists and diasporas have to address. Frankly speaking, migrancy is considered as a potential threat to the Palestinian national identity as it shatters the primordial connection and the natural relationship between place and identity. However, Palestinian diaspora writers are supposed to create new alternative spaces for articulating their endangered cultural identity. Randa Jarrar in her novel does not idealize Palestine and she is against the romanticization of Palestine. However, she acknowledges her roots and she also advocates the Palestinian national cause.

\section{A Map Of Home: The Quest for Home and Agency}

Randa Jarrar as a Palestinian-American has been one among the young writers whose fiction transcends geographical boundaries, rejects fixation, defies stereotypes, and portrays the daily struggle of the Palestinian individual. Her debut novel A Map of Home is a transnational piece of literature characterized by its engagements with the Palestinian history and culture. It is about a small family; the father Waheed, a Palestinian displaced after 1967 war into Egypt, and the mother, Fairuza, an Egyptian of Greek mother. They have two children; Nidali the protagonist and Gamal who has a minor role in the novel. The novel depicts the life of such family first in Kuwait and their movement to Egypt and finally to the United States. Nidali is the narrator of the novel, recounting her family's struggle and also reflecting her own experience of crossing borders and encountering other cultures.

As a female, Nidali is not only in search for home, she is also in pursuit of her agency. The novel is also described as coming-of-age story in which Nidali resists common stereotypes and social norms that are thought to determine the behavior of women in the Middle East. Waheed is depicted as a controlling and strict father who 
wants Nidali to be a professor and to most importantly adhere to his norms and regulations. The novel is loosely autobiographical narrative in which Jarrar herself seems to share a lot with Nidali-the protagonist. Moreover, the novel addresses the Palestinians issue and how Palestinians in diaspora view Palestine. Jarrar makes use of common Palestinian metaphors in the Palestinian discourse that are usually employed to represent the legitimacy of the Palestinian narrative. Olive is the national and symbolic tree in Palestine as it is grown there in large quantities. Whenever he misses home, Waheed keeps olive oil beside him not for its use but for the significance that the olive tree embodies. The olive tree has served as the ultimate symbol of rootedness and steadfastness, representing the Palestinian political strategy pursued from 1967 onwards (Ihab Saloul, 2012). It therefore functions in Randa Jarrar's novel as a cultural marker and a symbol of steadfastness. Its significance is realized only by Waheed Ammar who is put to represent the old generation displaced Palestinians. Nidali does not seem moved by such cultural markers nor does she even identify herself as displaced. She celebrates her homelessness and moving across borders seems for her as an essential step of personal evolution.

The other most important point to address here is the constant evolution of Nidali's conception of home. Jarrar is more preoccupied with an individual story of the search for home that takes place in the shadow of the history of Palestinian displacement that started in 1948 and that continues to have implications for the younger generations of Palestinians growing up in diaspora. The accounts encompass personal stories intertwined with the history of the Palestinian struggle. In her novel, Jarrar crosses borders and narrates the story of Nidali in Kuwait, Egypt, and finally Texas in the United States. Nidali, designated as the protagonist of the novel, is born in the United States to a Palestinian father, Waheed Ammar, and an Egyptian-Greek mother. She is hybrid, a mix of here and there, and she pronounces it:

Mama is an Egyptian, her mother was a Greek, my father is a Palestinian...I was Egyptian and Palestinian. I was Greek and American (8).

Though her parents are both Arab, their attitude and attachment to Palestine are different as they come from different Arab countries. Nidali from the very beginning finds herself straddling between two cultures, resulting in a sense of being out of place or a sort of estrangement in Nidali's cultural identification. Being a mix of different cultures and backgrounds, Nidali is set to explore such mix and to figure out a way for herself from the constant journeying and intermixing. She is cut free from an anchoring idea of home, and thus struggles to translate her Arab identity in an American context, especially in the first few months of her life in Texas (Bujupaj, 2016).

'Home' in Randa Jarrar's writing is experienced in highly aesthetic terms. Waheed Ammar idealizes Palestine and considers the loss of Palestine as a loss of paradise. Nidali has never been to Palestine; she only receives her narrative through her father. He tirelessly tries to teach her how to draw the map of historic Palestine, though the actual map is distorted and redrawn from times to times. Therefore, she imagines Palestine as a place of blossom. Eventually, her 'map' is complicated as it 
does not exist in reality; it is only imagined. The novel thus draws a figurative map that only features the vision of Nidali as a Palestinian diaspora. Home for her is found in movement; it is a 'mobile' kind of home.

The post-Nakhba memory is also invoked in the novel. Layla Maleh notes that "memory becomes a pretext that frames the content of the authors' experiences, and a pretext to construct a dual or juxtaposed picture of their mental and emotional make up" (Al Maleh, 2009). Jarrar, by depicting Waheed as an anxious Palestinian who is afraid of losing Palestine as an idea, is trying to create memory to save the story of Palestine from oblivion. Though she attempts to come to terms with the meaning of home in both literary and metaphorical senses, Jarrar acknowledges her Palestinian roots and voices the Palestinian anguish and constant journeying. In his book Catastrophe and Exile in the Modern Palestinian Imagination: Telling Memories, Ihab Saloul shows how oral history is significant for Palestinians to archive and sustain their culture in the present (Catastrophe and Exile in the Modern Palestinian Immagination:Telling Memories 175). In the same vein, the portrayal of Waheed Ammar in A Map of Home is a continuation of the Palestinian memory. Jarrar does not solely sympathize with Palestinians but also calls for rerooting and sprouting; a reconstruction of home wherever residency may be. It is a call for getting together in diaspora and maintaining the threads of Palestinian culture and identity.

Moreover, a close reading of the text reveals that it is intended to disrupt Orientalist constructions of the Middle East and the conceptions of Arab women in particular. Obviously, Jarrar's novel refuses polarization and disposes the dichotomy between 'East' and 'West', between 'Arab' and 'American', and between 'here' and 'there'. Moreover, Nidali resists being perceived as a cultural heroine and in doing so she disrupts the sacredness of social conventions (Bujupaj, 2016). By recounting her experience, Nidali demonstrates that coming-of-age is universal and that Arab women are not different. Opposing her father and resisting his conventional regulations for her own good, Nidali displays the ideal image of an Arab feminist. Indeed, her projection of feminism ideals does not mean negating the role of her father in shaping her personality. The tension between him and Nidali is rather looked at as a technique to advance the plot of the novel. In the novel Waheed, the father, is seen genuinely exerting effort toward his daughter's intellectual advancement. He attempts to push her to do well in school and he consequently nurtures her budding talent in creative writing. This makes him a significant factor in her identity construction even if she sometimes detests him. When asking her about what she wants to be, he recommends:

“...singing is not bad, but you can do better. You can be a doctor! A big professor of literature! Write poetry like I used to do. Write poetry and teach in English. Show those bastards the greatness of our literature (65).

Waheed contributes to Palestinizing Nidali and connecting her to the 'historic Palestine'. This has been his primary goal, to raise his children with love and attachment to their father's homeland. Nidali recounts her experience by saying:

Baba dictated history to me. I found about the Suez Canal...and how my geddo was a fighter called a 'free officer..Baba treated him a historical figure. 
He told her about his family in the Palestinian side, the connection to land, and how Palestinians fought all along... (67).

In terms of culture, Waheed cannot tolerate Nidali's attempts to assimilate. He seems to be against assimilation and integrating into the host society. Even in the United States, Waheed Ammar himself persists any changes. He does not want his children to get exposed to the American culture. He rather advices his daughter to only take the best of America, education and money. Nidali is frustrated by his regulations and she tries to run away twice. Rejecting her father's plans, Nidali murmurs:

"We are not here to make a friend". This is your Baba's mantra the entire time you are living under his roof. This is why he is in America but not you. You want a life, a concept you have just learned of (234).

It is easily observed that Waheed is afraid of losing Palestine as an idea. He therefore curtails Nidali's attempts for re-rooting herself. He already knows that her sense of home is fractured and this would weaken the Palestinian spirit and attachment to the eternal homeland-Palestine. Nidali and her mother have plans to settle down in the United States after years of movements and border-crossing. Nonetheless, Waheed does not seem interested in capitalizing his chances of re-sprouting and regrowth. He remains steadfast as the Palestinian olive tree.

\section{Conclusion}

In her novel, Randa Jarrar attempts to define what 'home' means to a Palestinian growing up as a diaspora. She vehemently advocates the Palestinian national cause, but she also cultivates her conception of home. In its essence, A Map of Home is a transnational text, and Randa Jarrar views herself as a cosmopolitan citizen. Though she upholds what constitutes Palestianness, 'home' for her exists in many places. In her characterization of Waheed Ammar, Jarrar attempts to represent the ideal Palestinian diaspora who remains faithful to his homeland. Moreover, Jarrar's fiction is very essential as narrative evidence that validates the story of Palestine, depicting the experiences of border-crossing, moving across countries as displaced, and living in the diaspora as stateless. Though the novel is often designated as a bildungsroman or a coming-of-age story, it brilliantly represents the condition of the contemporary Palestinian diasporas. It is full of humour and wit, yet it is satirical in its intent. Jarrar is not so much preoccupied with the notion of the romanticized home; she rather highlights the individual Palestinian experience. She even infuses feminist thoughts throughout the book.

\section{References}

Al Maleh, Layla. (2009). Arab Voices in Diaspora: Critical Perspectives on Anglophone Arab Literature. Rodopi.

Ashcroft, Bill and Pal Ahluwalia. (2001). Edward Said. London: Routledge.

Bujupaj, Ismet. (2016). "Parents and Daughters in two novels by Arab American Authors:Khalas Let Her Go." Anafora III.2 
Hanafi, Sari. (2003). "Rethinking Palestinians Abroad as a Diaspora:The Relationship between Diaspora and the Plestinian Territories." HAGAR International Social Science Review Vol.4 .1-2.

Jarrar, Randa. (2008). A Map of Home. Penguin Books.

Naguib, Assmaa. (2011). Representations of 'Home' from the Setting of 'Exile':Novels by Arab Migrant Writers. the University of Exeter.

Saloul, Ihab. (2012). Catastrophe and Exile in the Modern Palestinian Immagination:Telling Memories. Palgrave MacMillan.

Sirhan, Nadia. (2014). Folk Stories and Personal Narratives in Palestinian Spoken Arabic:A Cultural and Linguistic Study. Palgrave Macmillan.

Yi, Li. (2011). "Edward Said's Thoughts and Nationalism." Journal of Middle Eastern and Islamic Studies 5.3. 